\title{
THE ABUNDANCE AND DIVERSITY OF THRIPS (THYSANOPTERA: THRIPIDAE) ON CHILI (Capsicum annum L.) AND CAYENNE (Capsicum frutescens L.) IN BOGOR
}

\author{
Rudi Tomson Hutasoit, Hermanu Triwidodo, \& Rully Anwar \\ Tungro Research Desease Station, Indonesian Center for Food Crops Research and Development (ICFORD) \\ Jl. Poros Bulo, Timoreng Panua, Sidenreng Rappang, South Sulawesi 91651 \\ E-mail: untukpetani@gmail.com
}

\begin{abstract}
The abundance and diversity of thrips (Thysanoptera: Thripidae) on chili (Capsicum annuum L.) and cayenne (Capsicum frutescens L.) in Bogor. This research aimed to study the abundance and diversity of thrips on chili pepper and cayenne pepper plants. Observation of thrips was conducted on chili pepper and cayenne pepper in fourteen sites in four different locations in Bogor that are: Dramaga, Cibungbulang, Tenjolaya, and Cisarua. Thrips were collected from leaves and flowers from 10 plant samples that had been selected randomly. The thrips were identified and the number of thrips were calculated. The abundance of adults, nymphs, and total of thrips on the flowers of chili pepper was $0.39,0.01$, and 0.40 thrips/flower respectively. Meanwhile, the abundance of adults, nymphs, and total of thrips on the flowers of cayenne pepper was 0.36 , 0.02 , and 0.38 thrips/flower respectively. The abundance of adults, nymphs, and total of thrips on the leaves of chili pepper was $0.68,0.12$, and 0.81 thrips/twiq respectively. Meanwhile, the abundance of adults, nymphs, and total of thrips on the leaves of cayenne pepper was $0.47,0.14$, and 0.61 thrips/twiq respectively. Four species of thrips were found infesting flowers of chili pepper and cayenne pepper i. e. Thrips parvispinus, T. hawaiiensis, Scirtothrips dorsalis, and Haplothrips gowdeyi. Species of T. parvispinus, T. hawaiiensis, S. dorsalis belong to suborder of Terebrantia family Thripidae, meanwhile $H$. gowdeyi belongs to suborder Tubulifera family Phlaeothripidae. T. parvispinus is the most dominant species found infesting flowers and leaves of the chilli pepper and cayenne pepper were $71 \%$ and $56 \%$.
\end{abstract}

Key words: Haplothrips gowdeyi, S. dorsalis, T. parvispinus, T. hawaiiensis

\section{INTRODUCTION}

Chili is a vegetable that has high economic value and is widely cultivated by farmers from the lowlands to the highlands (Moekasan et al., 2014). Common types of chili cultivated in Indonesia are chili pepper (Capsicum annuum L.) and cayenne pepper (Capsicum frutescens L.). Spicy chili fruit is very popular in the society as a food flavor enhancer. Chili powder extract is used as a substitute for pepper to arouse appetite and flavoring. In addition, chili is also used as a medicinal herb in the pharmaceutical industry, food coloring industry, and producer of essential oils (Cahyono, 2003).

The harvested area of chili pepper production in Indonesia reaches $128,734 \mathrm{ha}$, with a production rate of $1,074,611$ tons and a productivity of 8.35 tons/ha of chili in 2014 (BPS, 2014). Cayenne pepper has a production harvest area of 134,882 ha, with a production rate of 800,484 tons, and productivity of 5.93 tons/ha (BPS, 2014). The data shows that there is still a gap between real productivity at the farm level and the potential productivity of chili pepper which can reach $12-15$ tons/ ha (Duriat et al., 2007) and cayenne pepper which can reach 12-20 tons/ha (Sujitno \& Dianawati, 2015).

Low productivity of chili production is caused by the infestation by plant pest organisms. At present there are 14 types of important pests that are reported to infest chili plants in the field, one of which is thrips (Sumarni \& Muharam, 2005). Loss of yield due to thrips infestation on chili pepper plantations was reported to reach 23\% (Vos et al., 1991).

Thrips are small insects with a body length of $0.5-5 \mathrm{~mm}$. The body length of some species in the tropics can reach $14 \mathrm{~mm}$ (Borror et al., 1996; Antonelli, 2003). Thrips are commonly found in the flowers and leaves of plants (Mound \& Collins, 2000). The role of thrips as a pest on plants is caused by their eating activities (whining and sucking). Symptoms of damage are in the form of silvery patches that become brownish in the leaves that can interfere with the photosynthesis process, so that the leaves permeate and the terminal shoots infested become stunted (Kirk, 2001).

Thrips in plants can also act as viral vectors (Riley et al., 2011). Some types of viruses that are transmitted 
by these insects include tomato spotted wilt virus (TSWV), lettuce spotted wilt virus (LSWF), pineapple yellow spotted virus (PYSV), Tip chlorosis, Kromneck diseases, and tobacco mosaic virus (TMV) (Klose et al., 1996; Sartiami, 2008).

Vos et al. (1991) stated that, from the results of Vierbergen's survey of chilli pests in Java in 1988, the Thrips parvispinus Karny species is found to be the most dominant in chili plants. Other species found infesting chili plantations are T. hawaiiensis, T. florum, and $T$. orientalis. The research results from Subagyo (2014) about thrips that infest horticultural plants in Bogor region, Cianjur Regency, and West Bandung Regency (Lembang) report that, T. parvispinus, and T. hawaiiensis (Terebrantia: Thripidae) as well as species 1 (Tubulifera: Phlaeothripidae) are found to be associated with chili plants. The role of these insects are very important as the main pest and vector for the spread of disease in chili plants. Research on the abundance and inventory of species in chili plantations needs to be done.

\section{MATERIALS AND METHODS}

Research Site. The study took place from November 2015 to March 2016. Sampling was carried out in four districts in Bogor Regency such as Dramaga, Cibungbulang, Tenjolaya, and Cisarua. Identification was carried out at the Insect Biosistematics Laboratory, Department of Plant Protection, Faculty of Agriculture, Institut Pertanian Bogor, West Java.

Sampling Technique. Observations of thrips on chili pepper and cayenne pepper were carried out in 14 plots scattered in four districts in Bogor Regency. Each type of chili consisted of seven plots of observation. The distribution of plots of observation of chili pepper was two plots in Cibungbulang District, two plots in Tenjolaya District, and three plots in Cisarua District. Distribution of plots of observation of cayenne pepper was two plots in Dramaga District, three plots in Tenjolaya District, and one plot in Cibungbulang District. At each plot, 10 randomly selected sample plants were selected. Thrips were observed in the flowers and leaves for both types of chili. Observation on flowers was done by patting flowers on a plastic container (diameter $=2.5 \mathrm{~cm}$ and height $=4.5 \mathrm{~cm}$ ) that had been filled with water. Each plant sample was observed for 10 flowers. Observation on leaves was done by patting leaf branches (10-15 leaves) on a plastic tray $(32 \times 25 \mathrm{~cm})$ filled with water. Each sample plant was observed in one leaf branch. Thrips were then collected into collection containers.
Each collection container was labeled with information on the date, location and part of the host plant observed. Sampling was done only once from 10:00 to 15:00 WIB. Thrips that had been collected into a collection container were then taken to the laboratory to be identified and counted for their abundance.

Abundance of Thrips. The samples collected from the field were then calculated for abundance based on the type and portion of chili plants observed. Imago and nymph of thrips collected were separated in calculations of population. The calculation of population process was carried out under a stereo microscope.

Identification. Thrips that had been collected from the field, were then identified to the species stage. A total of 31 and 28 imago individuals collected from the flowers and leaves in the chili pepper and 32 and 33 imago individuals collected from the flowers and leaves in cayenne pepper were randomly taken to be identified. Identification of thrips was done by making temporary microscope slides.

Making slide preparations refers to the method by Mound \& Kibby (1998) with the following work steps: the collected thrips image was inserted into a glass dish containing $70 \%$ alcohol to be separated from the carried dirt. The specimen was placed on a cover glass that was $13 \mathrm{~mm}$ in diameter, with the ventral part of the body was on top; then the two wings were stretched and the position of the antenna was straightened using a fine needle until the position was not stacked and clearly visible. After the position of the specimen was properly arranged, the Hoyer solution was dropped on the cover glass, then immediately closed with an object glass. After the object glass was placed, the position of the slide preparations was immediately reversed, so that the cover glass was on top of the object glass. The slide preparation was then dried for one week at $35-45^{\circ} \mathrm{C}$ in the drying box, then given clear nail polish on each edge of the glass cover and dried again for one day. Identification of thrips was based on identification keys from Mound \& Kibby (1998), Sartiami \& Mound (2013), and Subagyo (2014). The number of individuals per species from all identified samples was presented in the form of tables and pie charts, using the formula of:

$$
\mathrm{IS}(\%)=\frac{\sum \mathrm{n}}{\sum \mathrm{N}} \times 100
$$

IS $=$ Number of individuals per species

$\mathrm{n}=$ individual of $\mathrm{x}$ species

$\mathrm{N}=$ individual of all species 
Sex Ratio. Thrips that had been identified to species level were observed for their sex to see the ratio of the number of males and females. The calculation of sex comparison applied the following formula:

$$
\mathrm{NK}=\frac{\sum \mathrm{ib}}{\sum \mathrm{ij}}
$$

$$
\begin{aligned}
& \mathrm{NK}=\text { sex ratio } \\
& \mathrm{ib}=\text { female imago in } \mathrm{x} \text { species } \\
& \mathrm{ij} \quad=\text { male imago in } \mathrm{x} \text { species }
\end{aligned}
$$

Data Analysis. Identification results were tabulated in one table and diagram in Microsoft Excel software. Data analysis of abundance of thrips was examined through t-test with the help of SPSS 16 program.

\section{RESULTS AND DISCUSSION}

Abundance of Thrips. The observation of the abundance of thrips in the flowers and leaves showed that the abundance of imago, nymph, and total of thrips were not significantly different between each type of chili ( $p>0.05)$ (Table $1 \&$ Table 2$)$. These results indicated that thrips had no different preferences in the two types of chili tested. This is in accordance with the report by Vos et al. (1991) stating that thrips are the main pests in chili plantations (C. annuum and $C$. frutescens) in Indonesia.
The population of imago was significantly different from the nymph in the flower and leaf sections for both types of chili $(\mathrm{p}<0.05)$ (Table 3$)$. This was affected by the life span of the nymph phase which is shorter than the life span of the imago, thus causing the population of the imago to overlap. Hutasoit et al. (2017) stated that the phase averages of instar- 1 and instar- 2 nymph lasted 1.36 and 3.54 days. Abiotic factors such as temperature and humidity at the time of observation also had an effect. Berger et al. (2008) detailed that, at high temperatures imago will divert the energy it has to produce more eggs, while at low temperatures imago will accumulate the energy it has to form body structure.

The abundance of imago, nymphs and total of thrips found in the flower and leaf sections for both types of chili were relatively low (Table $1 \&$ Table 2). Yulianti (2008) reported that the thrips population could reach 19.22 individuals/plant with observations made on parts of young leaves, old leaves and flowers. In addition to biotic factors, thrips populations in plantations could be affected by abiotic conditions, especially rainfall, temperature, and humidity. Sampling in this study was conducted in November with conditions of rainfall and high humidity. Lewis (1973) reported that, rainfall can affect the thrips population, because it can kill nymphs and suppress the spread of thrips. Rain is an environmental factor that can directly or indirectly affect thrips. Heavy rain can cause thrips to fall from plants.

Table 1. Abundance of thrips in parts of flowers in chili pepper and cayenne pepper

\begin{tabular}{lccc}
\hline & \multicolumn{3}{c}{ Abundance of thrips (Individual/flower) } \\
\cline { 2 - 3 } Phase & \multicolumn{2}{c}{ (Means \pm SE) } & p-value \\
\cline { 2 - 3 } & Chilli pepper flower & Cayenne pepper flower & 0.865 \\
Imago & $3.92 \pm 1.44$ & $3.60 \pm 1.21$ & 0.631 \\
Nymph & $0.15 \pm 0.07$ & $0.20 \pm 0.04$ & 0.886 \\
Total & $4.08 \pm 1.51$ & $3.80 \pm 1.24$ & \\
\hline
\end{tabular}

SE: standard error.

Table 2. Abundance of thrips in parts of flowers in chili pepper and cayenne pepper

\begin{tabular}{lccc}
\hline & \multicolumn{3}{c}{ Abundance of thrips (Individual/flower) } \\
\cline { 2 - 3 } Phase & \multicolumn{2}{c}{ (Means \pm SE) } & p-value \\
\cline { 2 - 3 } & Chilli pepper flower & Cayenne pepper flower & \\
\hline Imago & $0.68 \pm 0.22$ & $0.47 \pm 0.08$ & 0.404 \\
Nymph & $0.12 \pm 0.06$ & $0.14 \pm 0.02$ & 0.844 \\
Total & $0.81 \pm 0.24$ & $0.61 \pm 0.08$ & 0.461 \\
\hline
\end{tabular}

SE: standard error. 
Vos et al. (1991) stated that, thrips become the main pest in chilli plantations especially during the dry season. According to Kakkar et al. (2010), hot temperatures and high humidity are the main supporting factors for the explosion of thrips populations in an area, so that in the rainy season the population of thrips often decreases even though high humidity is needed for the perfect development of thrips. Furthermore, it was explained that, at high temperatures, imago would divert its energy to produce more eggs, while at low temperatures, imago would accumulate its energy to form body structures (Berger et al., 2008).

Thrips Species in Chili Pepper and Cayenne Pepper. Based on the results of identification, four species of thrips were found infesting both the flower and leaf parts of chili peppers and cayenne peppers. The four species are T. parvispinus, T. hawaiiensis, S. dorsalis, and H. gowdeyi (Table 4). T. parvispinus, T. hawaiiensis, S. dorsalis is included in Subordo's Terebrantia Famili Thripidae, while H. gowdeyi is incuded in Subordo's Tubulifera familli Phlaeothripidae. The four species of thrips found were phytophagous insects with a wide range of host plants (Childers \& Nakahara, 2006). This result is in accordance with the research by Yulianti (2008) and Subagyo (2014) reporting that, T. parvispinus, T. hawaiiensis (Terebrantia: Thripidae), and H. gowdeyi spesies (Tubulifera: Phlaeothripidae) infest chili plantations in West Java.
Thrips parvispinus is the species that is found to be the most dominant in infesting the flowers and leaves in both types of chili (Figure $1 \&$ Figure 2). This result is in line with the report by Vos et al. (1991) stating that, $T$. parvispinus is the dominant species found to infest chili plants (Capsicum spp.) in Indonesia. Tyagi et al. (2015) argued the possibility of Indonesia being the source of this pest before the invasion of India. Yulianti (2008) also reported that, T. parvispinus species were found to predominantly infest chili plantations in the surrounding West Java region, with an average population of 8.18-19.22 thrips/plant. Sartiami \& Mound (2013) further explained that, T. parvispinus is the most commonly found species that is associated with horticultural plants on Java, with considerable damage to chili and potato plants. According to Mound \& Collins (2000), T. parvispinus is a polyphagous pest, but this species is more interested in flowers that are white and fragrant.

Thrips hawaiiensis, $S$. dorsalis, and $H$. gowdeyi were found in lower numbers of total imago individuals identified. These species are not suspected to be the main pests in chilli plants because they are not the dominant species found in chili plantations. These species are thought to only be temporary in chili cultivation. The main host is other plants around the map of observation. $S$. dorsalis was reported to have a broad host range, such as: nuts, rubber, mimosa, castor plant, rose, mango, tea, orange, banana, cotton, eggplant,

Table 3. Comparison of populations of imago and nymph in chili pepper and cayenne pepper

\begin{tabular}{lccc}
\hline \multirow{2}{*}{ Parts of plant } & \multicolumn{3}{c}{ Abundance of thrips (Means \pm SE) } \\
\cline { 2 - 4 } & Imago & Nymph & p-value \\
\hline Chilli pepper flower & $3.92 \pm 1.44$ & $0.15 \pm 0.07$ & 0.02 \\
Cayenne pepper flower & $3.60 \pm 1.21$ & $0.20 \pm 0.04$ & 0.01 \\
Chili pepper leaves & $0.68 \pm 0.22$ & $0.12 \pm 0.06$ & 0.03 \\
Cayenne pepper leaves & $0.47 \pm 0.08$ & $0.14 \pm 0.02$ & 0.00 \\
\hline
\end{tabular}

SE: standard error

Table 4. Species and sex of thrips in chili pepper and cayenne pepper

\begin{tabular}{|c|c|c|c|c|c|c|c|c|c|c|}
\hline \multirow{3}{*}{$\begin{array}{c}\text { Type of } \\
\text { chili }\end{array}$} & \multirow{3}{*}{ Parts } & \multirow{3}{*}{ (n) } & \multicolumn{8}{|c|}{ Species } \\
\hline & & & \multicolumn{2}{|c|}{ T. parvispinus } & \multicolumn{2}{|c|}{ T. hawaiiensis } & \multicolumn{2}{|c|}{ S. dorsalis } & \multicolumn{2}{|c|}{ H. gowdeyi } \\
\hline & & & Male & Female & Male & Female & Male & Female & Male & Female \\
\hline \multirow{2}{*}{$\begin{array}{l}\text { Chili } \\
\text { pepper }\end{array}$} & Flower & 31 & 5 & 14 & 1 & 1 & 0 & 1 & 0 & 9 \\
\hline & Leaves & 28 & 3 & 15 & 0 & 2 & 0 & 5 & 0 & 3 \\
\hline \multirow{2}{*}{$\begin{array}{l}\text { Cayenne } \\
\text { pepper }\end{array}$} & Flower & 32 & 8 & 18 & 0 & 1 & 0 & 0 & 0 & 5 \\
\hline & Leaves & 33 & 3 & 13 & 1 & 3 & 0 & 5 & 0 & 8 \\
\hline
\end{tabular}


grape, kiwi, mango, melon, strawberry, tobacco, tomato, potatoes, and pepper (Mound \& Palmer, 1981). In addition, the population of this species is generally found high in July and August (Kumar et al., 2014). T. hawaiiensis had been reported to infest various vegetable, tobacco, mango, orange and lantana plants (Reynaud et al., 2008). According to Nakahara \& Hilburn (1989), H. gowdeyi is a commonly found species that infests parts of flowers in cultivated plants. It was further explained that this species is also found to be dominant in cover crops or weeds (Childers \& Nakahara, 2006). For Etienne et al. (2015) the host species of this species are sorghum and corn.

Sex Ratio. Female imago was more dominant than male imago from the total sample identified. Comparison of sex ratio between males and females in T. parvispinus and $T$. hawaiiensis was $1: 3.1$ and $1: 3.5$, respectively. Meanwhile, the other sex ratios could not be determined because the species was only found to be of the same sex (female only) (Table 4). This ratio was affected by several factors such as type of reproduction, nutrition, temperature, and humidity. According to Graham \& Knight (1967), feed quality that is quite good, high reproductive power of females, and parthenogenetic species tend to produce higher females. Moritz (1997) stated that, temperature and humidity can affect the frequency of the number of males in a population. Yadav
\& Chang (2014) further explained that, the proportion of female thrips individuals was higher in the temperature range of $22{ }^{\circ} \mathrm{C}$ and $31^{\circ} \mathrm{C}$ compared to the temperature range of $16,19,25$, and $28{ }^{\circ} \mathrm{C}$. The life span of female imago which is longer than that of male imago also has an effect, so that female imago is more dominantly found in the field. The $S$. dorsalis and $H$. gowdeyi species cannot be determined by sex ratios, because all individuals in the species identified are only females.

Morphological Character. The T. parvispinus female imago is brown with a paler head and thoracic color than the color of the abdomen (bicolored) (Figure 3A). There are two pairs of ocellar setae in the head, and the ocellar seta III on the ocellar triangle line with a longer size than the oseli II (Figure 3B). The antenna consists of VII segments; III and IV sections are with sense cones in the form of forks, and VII section is very small (Figure 3C). The first and second venation of the wings have a complete set of setae (Figure 3D); reticulation pattern in medially metanotum (like a box of similar size). There are a pair of setae in the middle part of the metanotum that appear below the upper line of the metanotum (Figure 3E). The abdominal tergite on the VIII segment does not have a set of microtrichia (Figure 3F).

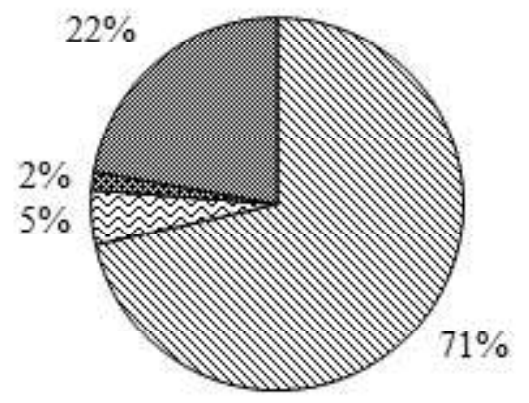

$\mathbb{T}$. parvispims

$\boxminus T$. hawailensis

줏 $S$. dorsalis

. $H$. gowdeyi

Figure 1. Percentage of individuals per species from the total sample in the flower part

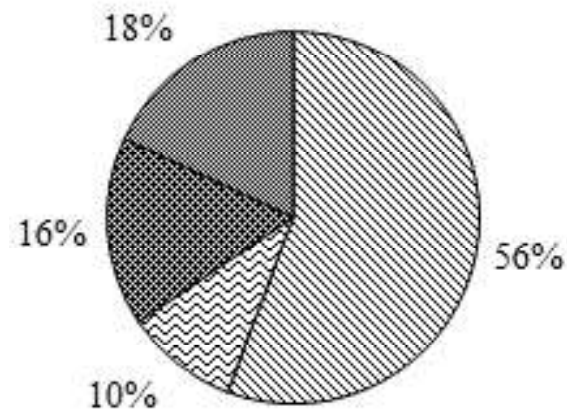

$\mathbb{Q}$ T. parvispims

$\boxminus T$. hawaiiensis

준 $S$ dorsalis

‥ H. gowdeyi

Figure 2. Percentage of individuals per species from the total sample in the leaf parts 
Imago T. hawaiiensis has a brown or bicolored body color (Figure 4A). There is a pair of ocellar setae in the head, ocellar seta III appears outside the ocellar triangle (Figure 4B). The antenna consists of VII segments (Figure 4C). Lines of setae at the first venation of the front wing are not complete (Figure 4D). The reticulation pattern at the top of the metanotum is transversal, whereas in the longitudinal center it is parallel. There are a pair of setae in the middle part of the metanotum that appear close to the upper line of the metanotum (Figure 4E). The abdominal tergite on the VIII segment has a complete, short, but irregular row of microtrichia (Gambar 4F).

$S$. dorsalis imago is characterized in a yellow body; there is a brown mark in the center of the abdominal tergite of the III-VII segment (Figure 5A). There are three pairs of ocellar setae in the head, ocellar seta III appears in the ocellar triangle (Figure 5B). The antenna consists of the VIII segment (Figure 5C). The lines of setae on the front wing venation are incomplete in the first and second rows (Figure 5D). The metanotum with a pair of setae is below the upper line of the metanotum (Figure 5E). The abdominal tergite in the VIII segment has a complete, regular and long set of microtrichia (Figure 5F).

H. gowdeyi imago is characterized by the dominant color of the body that is dark brown. The tip of the abdomen is tubular (Figure 6A). The antenna consists of VIII segments; the III and IV segments are yellow; the bottom of the V and VI segment are half yellow and half light brown. The III segment is with two sense cones while the IV segment is with four sense cones (Figure 6B). The middle wing surface has eight duplicate cilia (Figure 6C). Pronotum has five pairs of major capitate setae (Figure 6D).
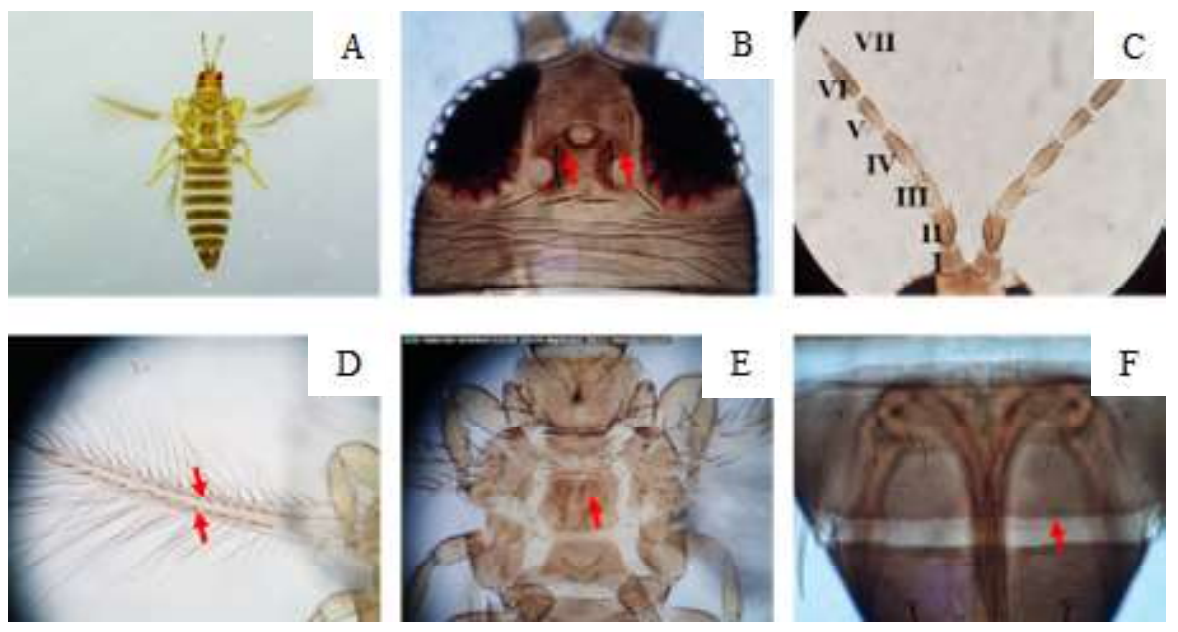

Figure 3. Morphological characters of T. parvispinus; (A) female imago, (B) head, (C) antenna, (D) wings, (E) metanotum, $(\mathrm{F})$ abdominal tergite.
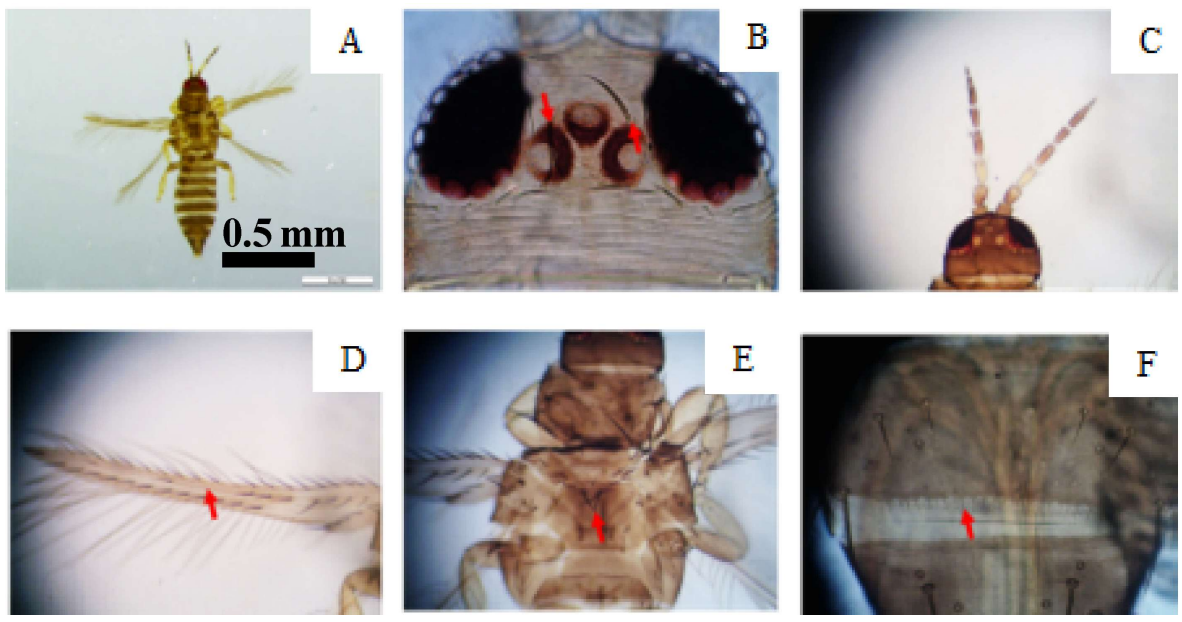

Figure 4. Morphological characters of T. hawaiiensis; (A) female imago, (B) head, (C) antenna, (D) wings, (E) metanotum, (F) abdominal tergite. 

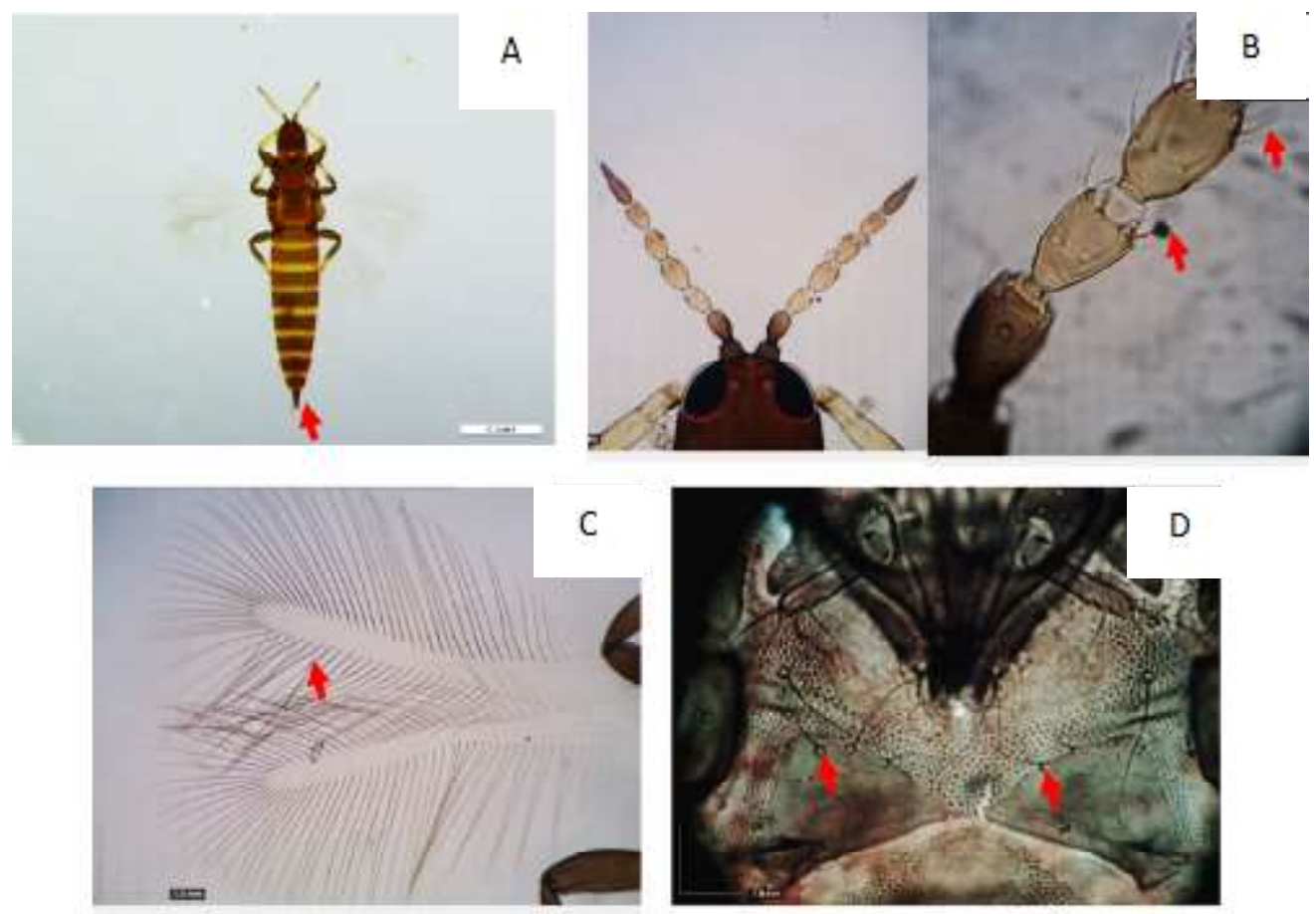

Figure 6. Morphological characters of $H$. gowdeyi; (A) female imago, (B) antenna, (C) wings, (D) pronotum.
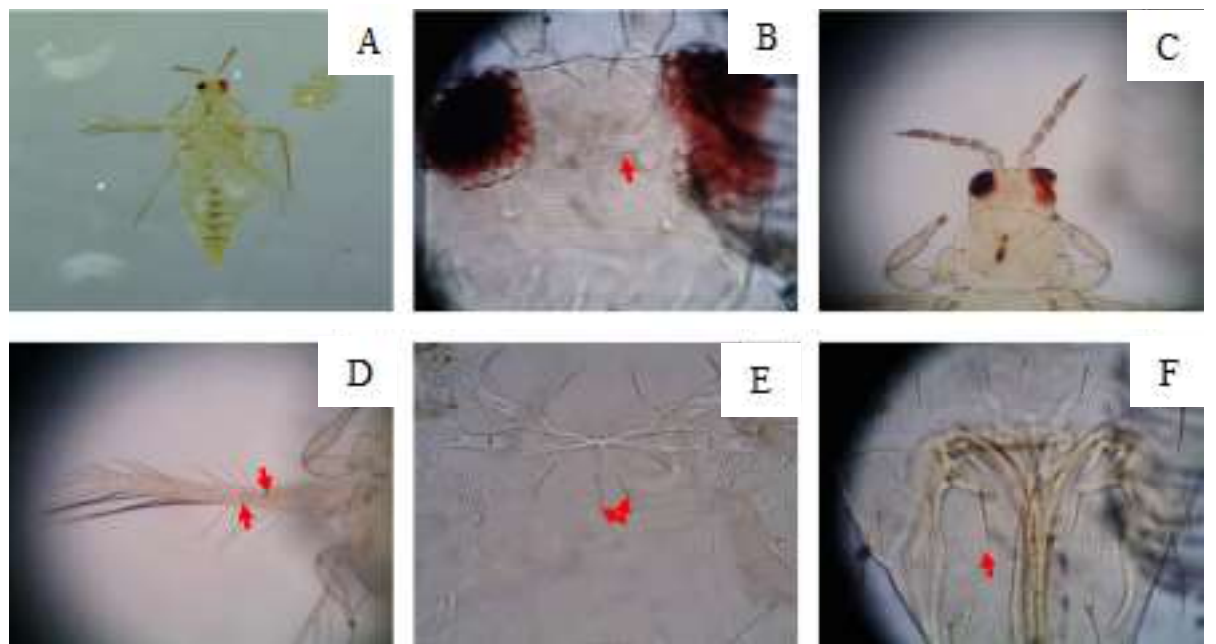

Figure 5. Morphological characters of S. dorsalis; (A) female imago, (B) head, (C) antenna, (D) wings, (E) metanotum, (F) abdominal tergite.

\section{CONCLUSION}

The abundance of imago, nymphs, and total of thrips in the flowers and leaves were not significantly different between the two types of chili. Species of thryps found infesting chilli pepper and cayenne pepper were $T$. parvispinus, $T$. hawaiiensis, $S$. dorsalis (Terebrantia: Thripidae) and H. gowdeyi (Tubulifera: Phlaeothripidae).

\section{ACKNOWLEDGMENT}

The author would like to thank the Directorate of Higher Education - the Ministry of Research and Technology and Higher Education for funding this research. 


\section{REFERENCES}

Antonelli AL. 2003. Thrips. Pest leaflet Series, Washington State University, Washington.

Berger D, Walters R, \& Gotthard K. 2008. What limits insect fecundity? Body size- and temperaturedependent egg maturation and oviposition in a butterfly. Funct Ecol. 22(3): 523-529.

[BPS] Badan Pusat Statistik. 2014. Produksi Cabai Besar, Cabai Rawit, dan Bawang Merah Tahun 2014. Badan Pusat Statistik Indonesia. Jakarta.

Borror DJ, Triplehorn CA, \& Johnson NF. 1996. Pengenalan Pelajaran Serangga. Ed ke-6. Gadjah Mada University Press, Yogyakarta.

Cahyono B. 2003. Cabai Rawit Teknik Budidaya dan Analisis Usaha Tani. Kanisius, Yogyakarta.

Childers C \& Nakahara S. 2006. Thysanoptera (thrips) within citrus orchards in Florida: species distribution, relative, and seasonal abundance within trees, and species on vines and ground cover plants. J. Insect Sci. 6(45): 1-19.

Duriat AS, Gunaeni N, \& Wulandari AW. 2007. Penyakit Penting Tanaman Cabai dan Pengendaliannya. Balai Penelitian Tanaman Sayuran, Bandung.

Etienne J, Ryckewaert P, \& Michel B. 2015. Thrips (Insecta: Thysanoptera) of guadeloupe and martinique: updated check-list with new information on their ecology and natural enemies. Fla. Entomol. 98(1): 298-304.

Graham SA \& Knight FB. 1967. Principles of Forest Entomology. McGraw-Hill Education, New York (US).

Hutasoit RT, Triwidodo H, \& Anwar R. 2017. Biologi dan statistik demografi Thrips parvispinus Karny (Thysanoptera: Thripidae pada tanaman Cabai (Capsicum annuum Linnaeus). JEI. 14(3): 107116.

Kakkar G, Seal DR, \& Kumar V. 2010. Common Blossom Trips, Frankliniella schultzei Trybom (Insecta: Thysanoptera: Thripidae). IFAS Extension, Florida (US).

Kirk WDJ. 2001. The pest and vector from the west: Frankliniella occidentalis. In: Marullo R \& Mound LA (Eds.). Proceedings of the 7th
International Symposium on Thysanoptera. pp. 33-42. Reggio Calabria, Italy.

Klose MJ, Sdoodee R, Teakle DS, Milne JR, Greber RS, \& Walter GH. 1996. Transmission of three strains of tobacco streak Ilarvirus by different thrips species using virus-infected pollen. $J$. Phytopathol. 144(6): 281-284.

Kumar V, Kakkar G, Seal DR, McKenzie CL, Colee J, \& Osborne LS. 2014. Temporal and spatial distribution of an invasive thrips species Scirtothrips dorsalis (Thysanoptera: Thripidae). Crop Prot. 55: 80-90.

Lewis T. 1973. Thrips: their Biology, Ecology, and Economic Importance. Academic Press, London.

Moekasan TK, Prabaningrum L, Adiyoga WA, \& dePutter H. 2014. Panduan Praktis Budidaya Cabai Merah Berdasarkan Konsepsi PHT. Penebar Swadaya, Jakarta.

Moritz G. 1997. Structure, growth and development. In: Lewis T (Ed.). Thrips and Crop Pest. pp. 1516. CABI, Wallingford.

Mound LA \& Collins DW. 2000. A South East Asian pest species newly recorded from Europe: Thrips parvispinus (Thysanoptera: Thripidae), its confused identity and potential quarantine significance. Eur. J. Entomol. 97(2): 197-200.

Mound LA \& Kibby G. 1998. Thysanoptera: an Identification Guide. 2nd Edition. CABI, Wallingford.

Mound LA \& Palmer JM. 1981. Identification, distribution and host-plants of the pest species of Scirtothrips (Thysanoptera: Thripidae). B. Entomol. Res. 71(03): 467-479.

Nakahara S \& Hilburn DJ. 1989. Annotated checklist of the Thysanoptera of Bermuda. J. New York Entomol. S. 97(3): 251-260.

Reynaud P, Balmes V, \& Pizzol J. 2008. Thrips hawaiiensis (Morgan, 1913) (Thysa-noptera: Thripidae), an Asian pest thrips now established in Europe. Bull. OEPP. EPPO Bull. 38(1): 155160.

Riley DG, Joseph SV, Srinivasan R, \& Diffie S. 2011. Thrips vectors of tospovirus. J. Integr. Pest Manage. 2(1): 1-10. 
Sartiami D. 2008. Kunci identifikasi ordo Thysanoptera pada tanaman pangan dan hortikultura. J. Ilmu Pert. Indones. 13(2): 103-110.

Sartiami D \& Mound LA. 2013. Identification of the terebrantian thrips (Insecta, Thysanoptera) associated with cultivated plants in Java, Indonesia. ZooKeys. 306: 1-21.

Subagyo VNO. 2014. Identifikasi Thrips (Insecta: Thysanoptera) yang Berasosiasi dengan Tanaman Hortikultura di Bogor, Cianjur, dan Lembang. Tesis. Institut Pertanian Bogor, Bogor.

Sujitno E \& Dianawati M. 2015. Produksi panen berbagai varietas unggul baru cabai rawit (Capsicum frutescens) di lahan kering Kabupaten Garut, Jawa Barat. Pros. Sem. Nas. Masy. Biodiv. Indon. 1(4): 874-877.

Sumarni N \& Muharam A. 2005. Budidaya Tanaman Cabai Merah. Balai Penelitian Tanaman Sayuran, Bandung.
Tyagi K, Kumar V, Singha D, \& Chakraborty R. 2015. Morphological and DNA barcoding evidence for invasive pest thrips, Thrips parvispinus (Thripidae: Thysanoptera), newly recorded from India. J. Insect Sci. 15(1):1-4.

Vos JGM, Sastrowiswojo S, Uhan TS, \& Setiawati W. 1991. Thrips on hot peppers in Java, Indonesia. In: Talekar NS (Ed.). Thrips in Southeast Asia. Proc. Regional Consultation Workshop, pp. 18-28. Bangkok, Thailand.

Yadav R \& Chang NT. 2014. Effects of temperature on the development and population growth of the melon thrips, Thrips palmi, on eggplant, Solanum melongena. J. Insect Sci. 14(78): 1-9.

Yulianti P. 2008. Spesies Trips (Ordo Thysanoptera) Pada Tanaman Cabai dan Tanaman Sekitarnya di Jawa Barat. Skripsi. Institut Pertanian Bogor, Bogor. 